\title{
Erzurum Ekolojik Koşullarında Yonca (Medicago sativa L.) Çeşit Adayının Performansının Belirlenmesi
}

\author{
Süreyya Emre DUMLU", Şerafettin ÇAKAL, Erdal AKSAKAL, Mustafa UZUN \\ Mustafa Merve ÖZGÖZ, Kadir TERZIOĞLU, Pinar UYSAL, \\ Murat ATICI, Ömer MENTESE
}

Doğu Anadolu Tarımsal Araştırma Enstitüsü Müdürlüğ̈̈, Erzurum

*e-posta: sureyyaemre.dumlu@tarim.gov.tr

Geliş Tarihi/Received: 24.08.2017 Kabul Tarihi/Accepted:30.10.2017

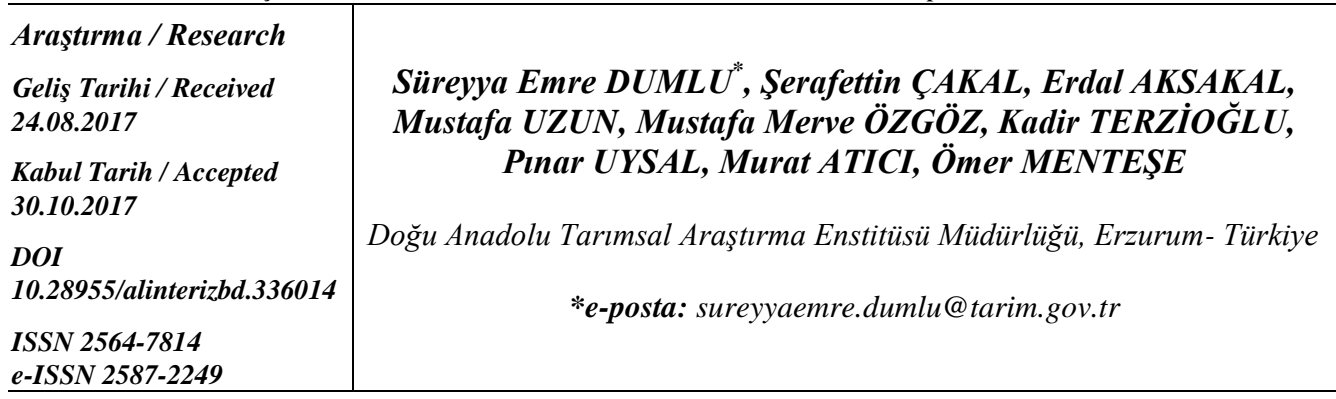

Öz: Çalışmanın amacı, Doğu Anadolu Bölgesi ekolojik şartlarına uyumlu yüksek verimli ve kaliteli ot tipi yonca geliştirmek için yürüttüğümüz yonca ıslah çalışmaları kapsamında çeşit adayı olarak belirlenen 1312/15 nolu hattın performansını ortaya koymaktır. Deneme Erzurum'da Pasinler ve Merkez lokasyonlarında 2002-2004 yılları arasında yürütülmüştür. Standart olarak Savaş çeşidi ve 1312 nolu ABD orijinli hat kullanılmıştır.

Araştırma sonuçlarına göre, çeşit ve hatlar arasında ana sap uzunluğu, ana sap kalınlığı, kuru ot verimi ve ham protein oranı bakımından istatistikî olarak farklar bulunmuştur. Çeşit ve hatlar arasında ADF ve NDF oranları bakımından fark bulunamamıştır. Buna göre, ana sap uzunluğu, ana sap kalınlığı ve dekara kuru ot verimi bakımından $1312 / 15$ ve 1312 en yüksek değeri verirken, Savaş çeşidi en düşük değere sahip olmuştur. Ham protein oranını bakımından Savaş çeşidinin, 1312/15 ve 1312 hatlarına göre daha yüksek değere sahip olduğu tespit edilmiştir.

Anahtar Kelimeler: Yonca, çeşit adayı, verim, kalite.

\section{Determination of The Performance of Alfalfa Variety Candidate in The Ecological Conditions of Erzurum}

\begin{abstract}
The aim of the study, the performance of the line 1312/15 wich is resistent to the ecological conditions of the Eastern Anatolia Region and is determined as the candidate varieties under the scope of alfalfa improvement studies carried out to develop high-yielding and high quality hay type alfalfa is to determined. The study was carried out in Pasinler district and center locations in Erzurum province between 2002-2004. As a standard alfalfa variety, Savaş variety and USA line were used.

As a result of the research, there were statistically significant differences in main stem lenght, main stem diameter, dry matter yield and crude protein percentage between the varieties and the lines. Furthermore, there was no difference between the varieties and the lines. in terms of ADF and NDF ratios. According to these results, while 1312/15 and 1312 had the highest value, the Savaş type had the lowest value in terms of main stem lenght, main stem diameter and dry matter yield per decare. It has been determined that the Savas type has a higher value than the lines 1312/15 and 1312 in terms of raw protein percentage.
\end{abstract}

Keywords: Alfalfa, variety candidate, yield, quality.

\section{GÍRIS}

Ülkemiz hayvancılığının en önemli sorunlarından birisini kaliteli kaba yem üretimindeki yetersizlik oluşturmaktadır. Tarımsal kaynaklarımız incelendiğinde; hayvan yemi üretimi kaynakları içinde doğal çayır-meralarımız ve yem bitkileri kültürü ile üretilen yem materyalinin çok önemli yer tuttuğu ortaya çıkmaktadır. 
Ülkemizde yaklaşık 14 milyon HB varlığının yaşam payının karşılanması için gerekli kaba yem

ihtiyacı 63,9 milyon ton hesaplanmaktadır. $\mathrm{Bu}$ ihtiyacın karşılanmasında mevcut kaba yem kaynaklarından sap-saman hariç yılda üretilen 50,9 milyon ton olmakta ve geriye 13 milyon tonluk kaliteli kaba yem açığı ortaya çıkmaktadır (Anonim, 2016). Ancak, doğal çayır ve mera kaynakları uzun süren ağır ve aşırı otlamalar nedeniyle hayvanların kaliteli kaba yem ihtiyacını karşılamada yetersiz kalmışlardır (Soya ve ark., 1997). Meralar üzerindeki bu baskıları kaldırmak için yem bitkileri ekilişlerinin teşvik edilmesi ve kaliteli kaba yemin sağlanması gereklidir. Yem bitkileri içerisinde yonca verim ve besleme yönünden önemli bir yere sahiptir. Geniş bir adaptasyon kabiliyeti, yüksek ot verimi, zengin besin değeri, kendinden sonra gelen ürünün verimini artırması, biçim sayısının yüksek ve ömrünün çok uzun olması ile yem bitkilerinin "imparatoriçesi" olarak bilinmektedir (Tan ve Serin, 1998; Avcıŏlu ve ark., 2009). Yonca ülkemizde en fazla yetiştirilen yem bitkilerinden biri olup ekim alanı 664.000 hektar ve yeşil ot üretimi ise yaklaşık 14 milyon ton'dur (Anonim, 2016). Doğu Anadolu ve Erzurum ili tarımsal üretiminde de yoncanın önemli bir payı bulunmaktadır. Öyle ki, yonca bölgemizde 6.564.217 dekar ekim alanı ile bölgemiz yem bitkisi ekim alanlarının \% 57,5'ine sahiptir. Erzurum'da ise 344.004 dekar alanda yetiştirilmekte ve ilimiz yem bitkisi ekim alanlarının \% 44,3'ünü oluşturmaktadır (Anonim, 2016). Bu kadar geniş bir ekim alanına ve üstün özelliklere sahip yoncanın ülkemizin her tarafında kolaylıkla yetiştirilebilmesi, ülkemizin ve bölgemizin ekolojisine uygun yeni çeşitlerin geliştirilmesini zorunlu kılmaktadır.

Yem bitkilerinde ana sap uzunluğu ve sap kalınlığı verime etki eden unsurlardandır. Özellikle yoncanın genç dönemlerinde ana sap ince ve yumuşak olmakta, bitki gelişimine bağlı olarak uzamakta ve kalınlaşmaktadır (Soya ve ark., 1997). Ana sap uzunluğu ve ana sap kalınlığının ot verimi üzerine doğrudan ve dolaylı etkileri olduğu bazı araştırıcılar tarafından tespit edilmiştir (Mcintosh and Miller 1981). Farklı yonca çeşitlerinin Ege Bölgesi şartlarına adaptasyonunu saptamak amacıyla yürütülen denemede, 7 farklı yonca çeşidinin ana sap uzunluklarının 61,56-67,5 cm arasında değiştiği, kuru ot verimlerinin ise en yüksek Pioneer-5715 (1573 kg da $\left.{ }^{-1}\right)$ ve en düşük Elçi (1178 kg da $\left.{ }^{-1}\right)$ çeşidinden elde edildiği bildirilmiştir (Aka ve Avcıoğlu, 2003). Benzer çalışmalarda yoncada kuru ot veriminin 1102-1266 kg da $\mathrm{kg}^{-1}$ 982-1797 $\mathrm{kg} \mathrm{da}^{-1}$ ve 1291-1781 kg da ${ }^{-1}$ aralıklarında olduğu bazı araştırıcılar tarafından bildirilmiştir (Şengül ve Tahtacıoğlu, 1996; Cevheri ve Avcıoğlu, 1998). Yoncada ana sap kalınlıklarının yıldan yıla değiştiğini bazı çeşitlerde 1,55-3,91 mm (Gülcan 1974), Kayseri ve Bilensoy-80 yonca çeşitlerinde ise 3,70-4,00 mm arasında değiştiği bildirilmiştir (Şeker ve ark., 2003).

Yonca bitkisi kaliteli bir ot üretmektedir. Hayvanların beslenmesinde büyük önem arz eden ham protein bitkiler tarafından yedek besin maddesi olarak kullanılmaktadır. Ham protein oranı yonca bitkisinin genç dönemlerinden samana kadar değişen biçim devrelerinde \%9,9-23,3 arasında değişmektedir (Açıkgöz, 1995). Isparta koşullarında Yılmaz ve Albayrak (2016) tarafından Bilensoy, Verko, Gea, Prosementi ve aday yonca çeşitlerinde yürüttükleri çalışmada en yüksek ham protein oranını \% 17,37 ile Aday çeşitte, en düşük ADF ve NDF oranlarını ise Bilensoy (sırasıyla, \%34,50 ve $\% 42,20)$ çeşidinde tespit etmişlerdir.

Yukarıda belirtilen üstün özellikleri nedeniyle bölgemiz ve ilimiz ekolojisine uygun, dayanıklı, yüksek verimli ve kaliteli yonca çeşit adayının performansını belirlemek amacıyla bu çalışma yürütülmüştür.

\section{MATERYAL VE YÖNTEM}

Denemede bitki materyali olarak Doğu Anadolu Tarımsal Araştırma Enstitüsü Müdürlüğü tarafından geliştirilen Savaş çeşidi, 1312/15 çeşit adayı ve ABD orijinli 1312 hattı kullanılmıştır. Savaş çeşidi ve 1312 hattı kontrol olarak kullanılmıştır. Çeşit adayı 1312/15, ABD orijinli 1312 hattı içerisinden belirlenen rekombinant non-dormant veya yarı dormant tek bitkiden "Tek Bitki Seleksiyon Metodu" kullanılarak değişik karakterler yönünden seleksiyonu yapılmıştır. Seleksiyon sonucu özellikle soğuklara dayanıklı erken ilkbaharda hemen büyümeye başlayan ve sonbaharda soğukların başlamasıyla diğer bitkilerin kış uykusuna geçerek kahverengi bir görünüme büründüğü devrede bile hala yeşil olarak kalabilen ve fazla miktarda sap oluşturup hem fazla miktarda tohum hem de ot üretebilen projenilerden elde edilmiştir.

Pasinler deneme alanı toprağı genellikle killi tınlı bünye ve hafif alkalin sınıfında, organik maddece az, fosfor bakımından ise orta sınıfta olduğu saptanmıştır (Özgül, 2003). Erzurum Merkez deneme alanı toprak yapısı tınlı bünyeye sahip, çok hafif alkalin karakterde, az kireçli, organik madde içeriği az ve tuzluluk problemi bulunmamaktadır. 
İklim verileri incelendiğinde Erzurum ve Pasinler lokasyonunda 2003 yılı vejetasyon döneminde ölçülen sıcaklık değerleri 2004 yılının aynı dönemine göre kısmen yüksek bulunmuştur. Her iki lokasyonda ve aynı vejetasyon döneminde ölçülen yağış değerlerinde ise 2004 yılının 2003 yılına göre daha yağışlı geçtiği tespit edilmiştir (Anonim, 2004). Sonuç olarak, denemenin yürütüldüğü yılların ortalaması üzerinden düşünüldüğünde Erzurum lokasyonu Pasinler lokasyonuna göre yağışlı ve daha serin olduğu ortaya çıkmıştır (Çizelge 1). Denemenin yürütüldüğü yıllarda iklimsel faktörlerin yonca bitkisinin yetiştirilmesini engelleyecek etkide bulunmamıştır. Bitkinin ihtiyacı olduğu yaz kritik periyotlarda sulama yapılmıştır.

Çizelge 1. Deneme yerlerine at iklim verileri

\begin{tabular}{|c|c|c|c|c|c|c|c|c|c|c|c|c|c|c|}
\hline Lokasyon & Yil & Ay & 1 & 2 & 3 & 4 & 5 & 6 & 7 & 8 & 9 & 10 & 11 & 12 \\
\hline \multirow{4}{*}{$\begin{array}{l}\text { Erzurum } \\
\text { Merkez }\end{array}$} & \multirow{2}{*}{2003} & Sicaklık & $-7,7$ & $-8,2$ & $-6,6$ & 4,4 & 11,6 & 14,5 & 18,9 & 20,0 & 13,8 & 8,8 & $-0,7$ & $-6,6$ \\
\hline & & Yağış & 17,7 & 30,7 & 32,9 & 81,4 & 29,9 & 45,7 & 18,5 & 5,1 & 19,3 & 90,9 & 36,1 & 16,1 \\
\hline & \multirow{2}{*}{2004} & Sicaklık & $-9,0$ & $-8,7$ & $-1,7$ & 4,0 & 9,7 & 14,5 & 17,9 & 19,6 & 13,8 & 7,9 & $-1,0$ & $-14,1$ \\
\hline & & Yağış & 14,3 & 90,0 & 33,7 & 36,0 & 121,7 & 40,7 & 17,9 & 1,3 & 6,0 & 27,4 & 43,6 & 8,2 \\
\hline \multirow{4}{*}{ Pasinler } & \multirow{2}{*}{2003} & Sicaklık & $-6,9$ & $-7,6$ & $-6,7$ & 4,2 & 12,0 & 14,9 & 19,1 & 19,8 & 14,5 & 10,1 & 0,1 & $-6,4$ \\
\hline & & Yağı̆ş & 13,4 & 72,1 & 38,0 & 73,5 & 33,0 & 25,0 & 2,0 & 5,0 & 29,0 & 84,0 & 45,0 & 18,0 \\
\hline & \multirow{2}{*}{2004} & Sicaklık & $-9,1$ & $-6,9$ & $-3,1$ & 4,8 & 10,0 & 14,5 & 17,6 & 17,3 & 15,2 & 9,6 & 1,1 & $-13,5$ \\
\hline & & Yağıș & 10,0 & 87,0 & 10,0 & 24,0 & 91,0 & 39,0 & 27,0 & 7,5 & 6,0 & 16,0 & 31,0 & 9,5 \\
\hline
\end{tabular}

Deneme 2002-2004 yılları arasında yürütülmüştür. Tesis yılı 2002 olup 2003 ve 2004 verim y1llarında tarımsal değerlerin ölçümleri yapılmıştır. Tesadüf Blokları Deneme Deseni’ne göre 3 tekerrürlü, sıra arası $20 \mathrm{~cm}$, parsel sıra sayıs1 8, parsel sıra uzunluğu $5 \mathrm{~m}$ olmak üzere deneme kurulmuştur. Denemenin 1. y1lında ekim öncesi $10 \mathrm{~kg} \mathrm{da}^{-1}$ saf fosfor ve ekimle birlikte $5 \mathrm{~kg} \mathrm{da}^{-1}$ saf azot uygulaması yapılmıştır. Denemenin 2. yılında fosfor, bakım gübrelemesi olarak uygulanmıștır. Hasatlar parsellerde \% 10 çiçeklenmenin görüldüğü tarihte, $5 \mathrm{~cm}$ anız yüksekliği olmak üzere yılda 3 biçim yapılmış, ihtiyaca göre de sulanmıştır (Tan ve ark., 1997). Denemede ana sap kalınlığı, ana sap uzunluğu ve kuru ot verimi gibi verim ve verim unsurları ölçülmüş, ham protein, ADF ve NDF kalite analizleri yapılmıştır. Her parselden alınan $500 \mathrm{~g}$ ot numunesi $70^{\circ} \mathrm{C}$ 'ye ayarlanmış etüvde 48 saat kurutulduktan sonra tartılmıştır (Anonim, 2001). Kalite analizleri için öğütülen otların Kjeldahl cihazıyla azot içerikleri belirlenmiş, ADF ve NDF analizleri ise ANKOM 1997'ye göre yapılmıştır. Deneme sonuçları ile Tohumluk Tescil ve Sertifikasyon Merkezi Müdürlüğüne (TTSMM) yapılan tescil başvurusu sonucu 1312/15 nolu çeşit adayımız Ömerbey yonca adıyla 2009 yılında tescil ettirilmiştir.

Elde edilen sonuçlar MSTAT-C paket programı kullanılarak varyans analizine tabi tutulmuştur.

\section{ARAŞTIRMA BULGULARI VE TARTIȘMA}

\section{Ana Sap Uzunluğu}

Araştırmada incelenen çeşit ve hatların ana sap uzunlukları Çizelge 2'de verilmiştir. Çizelge incelendiğinde iki yıllık ortalama verilerine göre iklim ve çevre şartlarına bağlı olarak lokasyonlardaki değişim ana sap uzunluğuna yansımıştır. Çeşit ve hatların ana sap uzunlukları \%1'de çok önemli bulunmuştur. Pasinler lokasyonunda $68,9 \mathrm{~cm}$, Erzurum lokasyonunda ise $64,0 \mathrm{~cm}$ saptanmıştır (Çizelge 2). 
Çizelge 2. Çeşit ve hatların ortalama sap uzunluğu değerleri $(\mathrm{cm})$

\begin{tabular}{llcccc}
\hline & & \multicolumn{4}{c}{ Çeşit/Hatlar } \\
\hline Yıllar & Lokasyonlar & Savaş & $\mathbf{1 3 1 2 / 1 5}$ & $\mathbf{1 3 1 2}$ & Ortalama \\
\hline $\mathbf{2 0 0 3}$ & Pasinler & 59,5 & 74,6 & 70,8 & 68,3 \\
& Erzurum & 59,6 & 74,6 & 71,0 & 68,4 \\
\hline Ortalama & & 59,5 & 74,6 & 70,9 & $68,3 \mathrm{~A}$ \\
\hline $\mathbf{2 0 0 4}$ & Pasinler & 63,0 & 74,0 & 71,6 & 69,5 \\
& Erzurum & 60,7 & 55,0 & 62,9 & 59,5 \\
\hline Ortalama & & 61,9 & 64,5 & 67,3 & $64,5 \mathrm{~B}$ \\
\hline Yıllar & Pasinler & 61,3 & 74,3 & 71,2 & $68,9 \mathrm{~A}$ \\
Ortalama & Erzurum & 60,1 & 64,8 & 67,0 & $64,0 \mathrm{~B}$ \\
\hline Ortalama & & $60,7 \mathrm{~B}$ & $69,5 \mathrm{~A}$ & $69,1 \mathrm{~A}$ & \\
\hline
\end{tabular}

*Aynı harfle işaretlenen ortalamalar birbirinden farksızdır. LSD Lokasyon:1,64, yıl:1,64, çeşit:2,01, Lokasyon xyll:2,32, Lokasyonxçeşit:2,84, Lokasyon xyllxçeşit:4,02

Çeşit ve hatların 2003 yılı ana sap uzunluğu $(68,3 \mathrm{~cm}), 2004$ y1lından $(64,5 \mathrm{~cm})$ çok önemli bir farkla yüksek bulunmuştur. Savaş çeşidi $60,7 \mathrm{~cm}$ ile en düşük ana sap uzunluğunu verirken, 1312/15 (69,5 cm) ve 1312 hatlarından $(69,1 \mathrm{~cm})$ en yüksek ana sap uzunluğu elde edilmiştir (Çizelge 2). 2003 y1lı 2004 yılına göre daha az yağışlı geçmesine rağmen, bu yılda artan sıcaklık ve buna bağlı olarak yapılan sulamalar bitki boyunun artmasında etkili olabileceği tespit edilmiştir. Nitekim Gençkan (1983), Aka ve Avcıoğlu (2003), yoncada ana sap uzunluğunun çevre şartlarına ve varyetelere göre 30-120 cm arasında değiştiğini bildirmektedirler. Pecetti ve ark., (1999) inceledikleri yonca çeşitlerinin ana sap uzunluğu bakımından istatistiki olarak önemli derecede birbirlerinden farklı olduklarını saptamışlardır.

\section{Ana Sap Kalınlı̆̆ı}

Ana sap kalınlığı bakımından çeşit ve hatlar, lokasyonlar ve y1llar arasında çok önemli farklılıkların olduğu tespit edilmiştir. Pasinler lokasyonunda 2,92 mm, Erzurum lokasyonunda 2,84 mm ana sap kalınlığı değerleri elde edilmiştir (Çizelge 3).

Çizelge 3. Çeşit ve hatların ortalama sap kalınlığı değerleri (mm)

\begin{tabular}{llcccc}
\hline \multicolumn{5}{c}{ Çeşit/Hatlar } \\
\hline Yllar & Lokasyonlar & Savaş & $\mathbf{1 3 1 2 / 1 5}$ & $\mathbf{1 3 1 2}$ & Ortalama \\
\hline $\mathbf{2 0 0 3}$ & Pasinler & 2,50 & 2,99 & 2,93 & 2,81 \\
& Erzurum & 2,52 & 2,99 & 2,93 & 2,81 \\
\hline Ortalama & & 2,51 & 2,99 & 2,93 & $3,81 \mathrm{~B}$ \\
\hline $\mathbf{2 0 0 4}$ & Pasinler & 2,92 & 3,08 & 3,11 & 2,86 \\
\hline Ortalama & Erzurum & 2,85 & 2,80 & 2,92 & $2,95 \mathrm{~A}$ \\
\hline Yıllar & Pasinler & 2,89 & 2,94 & 3,01 & $2,92 \mathrm{~A}$ \\
Ortalama & Erzurum & 2,71 & 3,04 & 3,02 & $2,84 \mathrm{~B}$ \\
\hline Ortalama & & 2,69 & 2,90 & 2,92 & $2,97 \mathrm{~A}$ \\
\hline
\end{tabular}

*Aynı harfle işaretlenen ortalamalar birbirinden farksızdır. L.S.D. Lokasyon:0,09, yıl:0,09, çeşit:0,10, Lokasyon xyıl:0,12, yılxçeşit: 0,15

2004 yılında $(2,95 \mathrm{~mm})$ elde edilen ana sap kalınlığı, 2003 y1lına $(2,81 \mathrm{~mm})$ göre daha yüksek bulunmuştur. Çeşit ve hatların ana sap kalınlığı bakımından en yüksek değer, aynı istatistik grubunda bulunan 1312/15 (2,97 mm) ve $1312(2,97 \mathrm{~mm})$ hatlarından elde edilirken, en düşük ana sap kalınlığı Savaş çeşidinde $(2,70 \mathrm{~mm}$ ) kaydedilmiştir (Çizelge 3). Savaş çeşidi Doğu Anadolu ekotipi özelliği gösterdiği için genetik olarak sapları daha ince olmaktadır (Şeker ve ark., 2003). Bitkilerde sap kalınlığının yüksek olması sindirimi zor olan ham selüloz içermesinden dolayı her zaman istenen bir özellik değildir. Sapın ince olması da yatma riskini artıracağı için her zaman tercih edilmez (Soya ve ark., 1997). Nitekim araştırmacıların yapmış oldukları çalışmalarda ana sap kalınlığının 2,24-4,00 mm arasında ve yıldan yıla değiştiği bildirilmekte olup elde edilen sonuçlarla uyum göstermektedir (Gülcan, 1974; Aka ve Avcıŏglu, 2003; Şeker ve ark., 2003).

\section{Kuru Ot Verimi}

Denemeden elde edilen kuru ot verimi 3 biçim toplamı olup, çeşit ve hatlar, lokasyonlar ve y1llar arasında çok önemli derecede farklılık göstermiştir (Çizelge 4). Pasinler lokasyonundan (1536,7 kg da $\left.{ }^{1}\right)$ en yüksek kuru ot verimi elde edilirken, Erzurum lokasyonu (1312 $\left.\mathrm{kg} \mathrm{da}^{-1}\right)$ düşük kuru ot verimini 
vermiştir. Yıllar arasındaki iklim farklılığı kuru ot verimini de çok önemli ölçüde etkilemiştir. 2003 Alınteri yılında elde edilen kuru ot verimi $\left(1553,1 \mathrm{~kg} \mathrm{da}^{-1}\right)$ ile 2004 yllı ile kiyaslandığında $\left(1295,7 \mathrm{~kg} \mathrm{da}^{-1}\right)$ çok yüksek bulunmuştur (Çizelge 4).

Çizelge 4. Çeşit ve hatların ortalama kuru ot verimleri $\left(\mathrm{Kg} / \mathrm{da}^{-1}\right)$

\begin{tabular}{llcccc}
\hline \multicolumn{5}{c}{ Çeşit/Hatlar } \\
\hline Yıllar & Lokasyonlar & Savaş & $\mathbf{1 3 1 2 / 1 5}$ & $\mathbf{1 3 1 2}$ & Ortalama \\
\hline $\mathbf{2 0 0 3}$ & Pasinler & 1235,3 & 1737,3 & 1603,7 & 1525,4 \\
& Erzurum & 1551,7 & 1681,3 & 1509,3 & 1580,8 \\
\hline Ortalama & & 1393,5 & 1709,3 & 1556,5 & $1553,1 \mathrm{~A}$ \\
\hline Or04 & Pasinler & 1256,1 & 1750,6 & 1636,9 & 1547,9 \\
& Erzurum & 989,2 & 1043,1 & 1098,5 & 1043,6 \\
\hline Yll & & 1122,7 & 1396,9 & 1367,7 & $1295,7 \mathrm{~B}$ \\
\hline Ortalama & Erzurum & 1245,7 & 1744,0 & 1620,3 & $1536,7 \mathrm{~A}$ \\
\hline Ortalama & & 1270,5 & 1362,2 & 1303,9 & $1312,2 \mathrm{~B}$ \\
\hline
\end{tabular}

*Aynı harfle işaretlenen ortalamalar birbirinden farksızdır, L.S,D, Lokasyon:90,50, yll:90,50, çeşit:110,85, Lokasyon xyıl:128,00, Lokasyon xçeşit:156,78, yılxçeşit:156,78

Çeşit ve hatlara göre en yüksek kuru ot verimi aynı istatistik grupta yer alan 1312/15 $\left(1553,1 \mathrm{~kg} \mathrm{da}^{-1}\right)$ ve $1312\left(1462,1 \mathrm{~kg} \mathrm{da}^{-1}\right)$ hatlarından elde edilirken, en düşük verim değeri Savaş çeşidinde $(1258,1 \mathrm{~kg}$ $\mathrm{da}^{-1}$ ) kaydedilmiştir (Çizelge 4). Savaş çeşidi soğuk bölgelere uyum sağlamış dormant çeşit olması nedeniyle düşük verimli bulunmuştur. Fakat ABD orijinli 1312 hattın projenilerinden olan 1312/15 aday çeşit sonbaharda soğukların başlamasıyla diğer bitkilerin kış uykusuna geçerek kahverengi bir görünüme büründüğü devrede bile hala yeşil olarak kalabilen ve fazla miktarda sap oluşturup nondormant olduğu için sonbahar ve ilkbaharda dormant çeşitlere göre daha fazla kuru ot üretmektedir. Nitekim non-dormant çeşitlerin sonbahar ve ilkbaharda dormant çeşitlere göre daha yüksek ot ürettiği Cunningham ve ark., (1998) tarafindan bildirilmiştir. Kuru ot verimlerindeki değişimlerin, bitki genetik faktörlerinden, iklim ve çevre şartlarından kaynaklandığı bir çok araştırmacı tarafindan bildirilmektedir (Hill and Baylor, 1983; Simith ve ark., 1991; Altınok ve Karakaya, 2002). Denemenin yürütüldüğ̈̈ 2003 yılı 2004 yılına göre daha az yağışlı geçmesine rağmen, bu yılda sıcaklık değerlerinin yüksek ve buna bağlı olarak yapılan ilave sulamaların ana sap uzunluğunda artış sağladığı ve bununda kuru ot verimine olumlu yansıdığı düşünülmektedir. Nitekim, ana sap uzunluğunun ot verimi üzerine doğrudan ve dolaylı etkilerinin olduğu bazı araştırıcılar tarafindan belirtilmiştir (Mcintosh and Miller, 1981). Denemeden elde edilen bulgulara benzer pek çok araştırma (Şengül ve Tahtacioğlu, 1996; Tahtacioğlu ve ark., 1996; Cevheri ve Avcioğlu, 1998; Aka ve Avcioğlu, 2003; Yılmaz ve Albayrak, 2016) sonuçları bulunmaktadır.

\section{Kalite Değerleri}

İki lokasyonda yürütülen yonca çeşit ve hatlarına ait bazı kalite değerlerine ilişkin istatistik analiz sonuçları Çizelge 5'de sunulmuştur. Çizelgeden de anlaşılacağı gibi ham protein oranı bakımından çeşit ve hatlar ile lokasyonlar arasındaki farkl1lıklar çok önemli bulunmuştur. ADF (Acid Detergent Fiber) oranlarının çeşit ve hatlar ile lokasyonlar arasında istatistikî olarak birbirinden farklı olmadığı saptanmıştır (Çizelge 5). Önemli bir kalite göstergesi olan NDF (Neutral Detergent Fiber) oranlarının da çeşit ve hatlar ile lokasyonlar arasında istatistikî olarak birbirinden farklı olmadığı tespit edilmiş̧ir (Çizelge 5).

Çizelge 5. Çeşit ve hatların bazı kalite değerleri (\%)

\begin{tabular}{lccccccccc}
\hline Lokasyonlar & \multicolumn{3}{c}{ Erzurum } & \multicolumn{3}{c}{ Pasinler } & \multicolumn{3}{c}{ Ortalama } \\
\hline Çeşit/Hat & HP & ADF & NDF & HP & ADF & NDF & HP & ADF & NDF \\
\hline Savaş & $19,08 \mathrm{~A}$ & 35,76 & 40,95 & $18,93 \mathrm{~A}$ & 42,05 & 44,38 & $19,01 \mathrm{~A}$ & 38,91 & 42,67 \\
$\mathbf{1 3 1 2 / 1 5}$ & $17,13 \mathrm{~B}$ & 38,03 & 42,67 & $16,43 \mathrm{~B}$ & 42,60 & 45,88 & $16,78 \mathrm{~B}$ & 40,32 & 44,28 \\
$\mathbf{1 3 1 2}$ & $17,64 \mathrm{~B}$ & 36,26 & 41,50 & $17,97 \mathrm{AB}$ & 40,92 & 45,63 & $17,81 \mathrm{AB}$ & 38,60 & 43,57 \\
\hline F & $* *$ & Ö,D & Ö,D & $* *$ & Ö,D & Ö,D & $* *$ & Ö,D & Ö,D \\
LSD & 1,62 & - & - & 1,58 & - & - & & & \\
\%CV & 7,32 & 11,71 & 9,47 & 2,36 & 5,11 & 3,12 & & & \\
\hline
\end{tabular}

Denemede, Erzurum Merkez ve Pasinler lokasyonunda Savaş çeşidi (sırasıyla \%19,08-18,93) en yüksek ham protein oranını verirken, her iki lokasyonda 1312 hattı (sırasıly \%17,64-17,97) ve 1312/15 aday çeşit (sırasıyla \%17,13-16,43) en düşük ham protein oranını vermiştir (Çizelge 5). 
Pasinler lokasyonunda ABD orijinli 1312 hattı ham protein oranı bakımından Savaş çeşidinden düşük

değer vermesine rağmen Savaş çeşidine benzerlik gösterdiği kaydedilmiştir. Savaş çeşidinin sapının daha ince ve bol yapraklı olması nedeniyle ham protein oranının yüksek olduğu düşünülmektedir. Nitekim Doğu Anadolu ekotipi özelliği gösteren Savaş çeşidinin genetik olarak saplarının daha ince ve bol yapraklı olduğu Şeker ve ark., (2003) tarafından bildirilmiştir.

\section{SONUÇLAR VE ÖNERILER}

Bu çalışma, Doğu Anadolu Tarımsal Araştırma Enstitüsü Müdürlüğü’nün bölgenin ekolojik koşulları için çeşit geliştirme amacıyla yürüttüğü yonca ıslah çalışmaları kapsamında yürütülmüştür. İntrodüksiyon materyali olarak kullanılan ABD orijinli 1312 hattı projenilerinden seçilen non-dormant 1312/15 çeşit adayı, standart olarak kullanılan Savaş çeşidi ve 1312 hattı ile verim, verim unsurları ve bazı kalite değerleri bakımından iki yıl ve iki lokasyonda karşılaştırılmıştır. Deneme sonuçlarına göre çeşit adayı 1312/15'in kontrol Savaş çeşidine ve 1312 hattına göre verim, verim unsurları ve bazı kalite değerleri bakımından yüksek performans gösterdiği ortaya çıkmıştır. Bu amaçla 1312/15 nolu çeşit adayımızın tescili için 2004 yılında Tohumluk Tescil ve Sertifikasyon Merkezi Müdürlüğü'ne (TTSMM) yapılan başvuru sonucu 2009 yılında Ömerbey yonca ismiyle tescil ettirilerek bölge tarımına kazandırılmıştır.

KAYNAKLAR

Açıkgöz, E., 1995. Yem Bitkileri. Uludağ Üniversitesi Ziraat Fakültesi Yayınları: 7-025-0210, Ders Kitabı: 456, Bursa.

Aka, M.A., Avcıoğlu R., 2003. Selçuk koşullarında 7 farklı yonca çeşidinin verim ve diğer bazı verim özellikleri üzerinde araştırmalar. Türkiye V. Tarla Bitkileri Kongresi, 13-17 Ekim, Diyarbakır, s. 533-536.

Altınok S. and Karakaya, A., 2002. Forage yield of different alfalfa cultivars under Ankara conditions. Journal of Agricultural, 26, 11-16.

ANKOM Technology Corporation, 1997. Opretaor's Manuel; Ankom 200/220 Fiber Analyzer. Ankom Thec, Corporation, Macedon.

Anonim, 2001. Tarımsal Değerleri Ölçme Denemeleri Teknik Talimatı. Gıda Tarım ve Hayvancılık Bakanlığı, Tohumluk Tescil ve Sertifikasyon Merkezi Müdürlüğü, Ankara.

Anonim, 2004. Tarımsal Yapı ve Üretim, Başbakanlık DİE Ankara.

Anonim, 2016. Türkiye Yem Bitkileri Üretimi, Mevcut Durumu ve Desteklemeleri. Bitkisel Üretim Genel Müdürlüğü, Tarım Havzaları Dairesi Başkanlığı istatistikleri, Ankara.

Avcıoğlu, R., Hatipoğlu, R., ve Karadağ, Y., 2009. Yem Bitkileri (Baklagil Yem Bitkileri). Tarımsal Üretim ve Geliştirme Genel Müdürlüğü Yayınları, Cilt II, 545, İzmir.

Cevheri, A.C. ve Avcıŏglu, R., 1998. Bornova koşullarında 11 farklı yonca çeşidinin verim ve diğer bazı verim özellikleri üzerinde araştırmalar. Yüksek lisans tezi, Ege Üniversitesi Fen Bilimleri Enstitüsü, (Basılmamış), İzmir.

Cunningham, S.M., Volenec, J.J. and Teuber, L.R., 1998. Plant survival and root and bud composition of alfalfa populations selected for contrasting fall dormancy, Crop Science, 38, 962-969.

Gençkan, M.S., 1983. Yembitkileri Tarımı. Ege Üniversitesi Yayınları No: 519, İzmir.

Gülcan, H., 1974. Çukurova sulu şartlarında yetiştirilen önemli yonca varyetelerinin bazı biyolojik, morfolojik özellikleri ve bunların verimle ilişkileri. Doktora tezi, Çukurova Üniversitesi Fen Bilimleri Enstitüsü, (Basılmamış), Adana.

Hill, R.R., Baylor, J.E., 1983. Genotype x environment interaction analysis for yield in alfalfa, Crop Science, 23, 811-815.

Mcintosh M.S., Miller D.A., 1981. Genetic and soil moisture effects on the branching root traits in alfalfa, Crop Science, 21, 15-18.

Özgül, M., 2003. Erzurum yöresinde yaygın olarak bulunan büyük toprak gruplarının sınıflandırılması ve haritalanmas1, Doktora tezi, Atatürk Üniversitesi Fen Bilimleri Enstitüsü, (Basılmamış), Erzurum.

Pecetti, L., Piano, E. and Romani, M., 1999. Variation in morphophysiological traits of exotic lucerne Germplam in Northern Italy, Proc, XIII. Eucarpia Medicago spp, Group Meeting Perugia, 13-16 September, Italy, pp. 44-51.

Simith, S.E., Aldos, A., Warburton, M., 1991. Morpholigical and agronomic variation North Africa and Arabian alfalfa's. Crop Science, 31, 1159-1163.

Soya, H., Avcıoğlu, R., Geren, H., 1997. Yem Bitkileri. Hasad Yayıncılık, İstanbul.

Şeker, H., Tahtacioğlu, L. ve Aygün, C., 2003. Doğu Anadolu yoncasından elde edilen hatların Kayseri ve Bilensoy-80 çeşitleriyle karşılaştırılmalı genel mahsul büyüme oranları ve bazı morfolojik özellikler. Atatürk Üniversitesi Ziraat Fakültesi Dergisi, 34(4), 303-307.

Şengül, S., Tahtacıoğlu, L., 1996. Erzurum ekolojik şartlarında farklı yonca çeşit ve hatlarında ot ve ham protein verimlerinin belirlenmesi. Türkiye III. Çayır Mera ve Yembitkileri Kongresi, 17-19 Haziran, Erzurum, s. 608-614. 
Tahtacıoğlu, L., Mermer, A. ve Avcı, M., 1996. Yonca Çeşit ve Hatlarının Erzurum Ekolojik Koşullarına Adaptasyonu, Gıda Tarım ve Hayvancılık Bakanlığı, Doğu Anadolu Tarımsal Araştırma Enstitüsü Yayın No: 18, Erzurum.

Tan, M., Serin, Y., Yolcu, H., 1997. Erzurum şartlarında yoncada ot ve tohum alma imkanları üzerinde bir araştırma, Atatürk Üniversitesi Ziraat Fakültesi Dergisi, 29(2), 219-229.

Tan, M., Serin, Y., 1998. Doğu Anadolu Bölgesi kaba yem üretimi, ihtiyacı, yem bitkileri tarımının geliştirilmesi, Doğu Anadolu Tarım Kongresi, 14-18 Eylül, Erzurum, s. 1052.

Yılmaz, M., Albayrak, S., 2016. Isparta ekolojik koşullarında bazı yonca (Medicago sativa L,) çeşitlerinin ot verim ve kalitelerinin belirlenmesi. Tarla Bitkileri Merkez Araştırma Enstitüsü Dergisi, 25(1), $42-47$. 